\title{
Screening and Identification of Strains With High Lignocellulose-degrading Enzyme Production From Endophytic Fungi of Taxillus Chinensis
}

\author{
Lisha Song Song \\ Guangxi Botanical Garden of Medicinal Plants \\ Limei Pan Pan \\ Guangxi Botanical Garden of Medicinal Plants \\ Ni Jiang Jiang \\ Guangxi Botanical Garden of Medicinal Plants \\ Jine FU FU ( $\square$ duanwei3014@163.com ) \\ Guangxi Botanical Garden of Medicinal Plants \\ Lingyun Wan Wan \\ Guangxi Botanical Garden of Medicinal Plants \\ Shugen Wei Wei \\ Guangxi Botanical Garden of Medicinal Plants
}

\section{Research Article}

Keywords: Taxillus chinensis, endophytic fungi, lignocellulosic degrading enzymes, screening, identification

Posted Date: November 30th, 2021

DOI: https://doi.org/10.21203/rs.3.rs-1084841/v1

License: (c) (7) This work is licensed under a Creative Commons Attribution 4.0 International License. Read Full License 


\section{Abstract}

Taxillus chinensis is an extensively used medicinal herb in the traditional as well as modern systems of medicines. It is a perennial hemiparasitic plant, which is difficult to propagate artificially because of its low parasitic rate. Successful parasitism of parasitic plants is to fuse their tissues and connect their vasculature to the host vasculature building a physiological bridge, which can efficiently withdraw water, sugars and nutrients from their host plants. It is reported that endophytic fungi play an important role in cell wall degradation and fusion, which is the key forming process of the physiological bridge. Therefore, in this study, the endophytic fungi from T. chinensis of different hosts were isolated, and then the organisms that could degrade the main components of the cell walls were screened out using a medium consisting of guaihuol and cellulose degradation capacity. The results showed that five strains with high enzyme activities for lignocellulosic degradation were screened out from 72 endophytic fungi of $T$. chinensis. The laccase and cellulase activities of five strains reached their peaks at day 7, and the highest enzyme activities of these two enzymes were found in strain P6, which was 117.66 and $1.66 \mathrm{U} / \mathrm{mL}$, respectively. Manganese peroxidase of strain 4 and lignin peroxidase of strain $\mathrm{N} 6$ also reached their peaks at day 7 and were the highest among the 5 strains, with enzyme activities of 11.61 and $6.64 \mathrm{U} / \mathrm{mL}$, respectively. Strains 4, 15, 31, N6 and P6 were identified as Colletotrichum acutatum, Nigerrospora sphaerica, Exserohilum rofolium, Diaporthe phaseolorum and Pestalotiopsis arceuthobii, respectively, according to their morphological and molecular biology properties.

\section{Introduction}

Taxillus chinensis belonging to the Loranthaceae family is mainly distributed in the southern and southwestern areas of China. The dry stems and branches with leaves of T. chinensis are commonly used ingredients in traditional Chinese medicinal and are called "Sang Ji Sheng" in China. T. chinensis has a high medicinal value. It is used for relief from rheumatic conditions, reinforcement of the liver and kidneys, strengthening of tendons and bones and prevention of abortions ${ }^{1}$. T. chinensis is a semi-parasitic plant with diverse hosts ${ }^{2}$. However, T. chinensis is also used as raw materials for making parasitism tea in China, which is a traditional Chinese food healthcare tea and it is exported to nearly 30 countries in Southeast Asia ${ }^{3}$. Therefore, the demand of $T$. chinensis is constantly rising in the global herbal market due to its immense therapeutic potential. However, T. chinensis is mainly derived from wild resources, which cannot fully meet the increasing demand of the market. The artificial cultivation of $T$. chinensis is an effective measure to balance market supply and demand.

However, T. chinensis is a perennial hemiparasitic plant, which is difficult to propagate artificially because of its low parasitic rate. An essential component of parasitic success in parasitic plants is the ability to fuse their host cell walls and connect their vasculature by a specialized organ known as the haustorium, thus forming a physiological bridge ${ }^{4-7}$. This allows transfer of not only water and nutrients into the parasite but also macromolecules, including mRNAs ${ }^{8}$ and proteins ${ }^{9}$. Thus, the host's cell wall is the first barrier to the formation of a physiological bridge. Interestingly, studies have found that penetration of the haustorium does not cause significant damage to host plant cells. For example, the haustorium of Striga hermonthica does not cause endodermis cell damage of the host plant during penetration ${ }^{10-12}$. This can be achieved in different ways. In most parasitic plants of the Orobanchaceae family, a large number of enzymes related to cell wall degradation have been found in the parasitic process ${ }^{12-13}$. For example, pectin methyl esterase which can degrade pectin, is found at the hastorium puncture sites of Oroanche cumana and Phelipanche aegyptiaca ${ }^{14}$. Other cell wall modifiers, such as dilatases and enzymes with transglucanase activity have been shown to peak during the penetration period of dodder infection of WM-xylglucan. In contrast, inhibition of these WMxylglucan modifiers reduced the chance of successful dodder invasion ${ }^{15}$. Therefore, enzymes related to cell wall degradation play an important role during the parasitic process.

It is well known that the main components of plant cell walls are lignin and cellulose. The role of fungi in degrading these substances has been widely reported, but these reports have been mainly focused on some types of wood rotting fungi, such as the white rot fungus Phanerochaete chrysosporium Burds, Ceriporiopsis subvermispora (Pila T) Gilb. \& Ryvarden, and the brown rot fungus Postia placenta (Fr.) M.J. Larsen \& Lombard, etc ${ }^{16-18}$. White rot fungi are considered to be the most effective and are the main microorganisms for lignin degradation. White rot fungi have formed a unique degradation system in the long-term biological evolution process. Laccase, manganese peroxidase and lignin peroxidase jointly constitute the lignin degradation enzyme system of white rot fungi ${ }^{19}$, and it can degrade all the components of plant cell walls, including lignin, cellulose and hemicelluloses ${ }^{20-21}$.

Currently, little is known about the mechanism of endophytic fungi in plant cell wall degradation, but the role of wood rot fungi in lignin degradation provides a reference for studying the parasitic mechanism of $T$. chinensis from the perspective of endophytic fungi. In this study, the endophytic fungi were isolated from T. chinensis of different hosts, and then the strains producing chromogenic and transparent circles were screened using the selective and cellulose solid media containing guaiacol as an indicator. This method showed that the strains had the highest ability for lignin and cellulose degradation ${ }^{22-24}$. These strains were selected for qualitative determination of enzyme activities of laccase, lignin peroxidase, manganese peroxidase and cellulase. The strains with high lingocellulosic degradation enzymes production were screened out and their classification status was established according to their morphology and molecular biology characteristics. Exploring the mechanism of the endophytic fungi of $T$. chinensis in the cell wall degradation during the parasitic process not only provides practical guidance and theoretical basis for the propagating of $T$. chinensis, but it can also provide new research ideas for the parasitic mechanisms of other parasitic plants.

\section{Materials And Methods}

\section{Sample Collection of T. chinensis}

In January 2020, the roots of T. chinensis from different hosts including Morus alba, Prunus salicina, Phellodendron chinense, Dalbergia odorifera, Bauhinia purpurea, Diospyros kaki and Dimocarpus longann were collected in the T. chinensis planting base of Cenxi Funing Village, Wuzhou City (111 ${ }^{\circ} 51^{\prime} 14^{\prime \prime} \mathrm{E}$, $22^{\circ} 58^{\prime} 12^{\prime \prime N}$ ). We collected 3-5 haustoria of $T$. chinensis from the same host plants. 


\section{The Raw Materials}

The wheat bran was purchased from Zhonghe Modern Agricultural Development Group Co. Ltd. The pretreatment of wheat bran was based on Tao Yanjuan's method ${ }^{37}$ with some modifications. The wheat bran was crushed through a 40 -mesh sieve, then 10 times volume of distilled water was added, and the mixture was crushed by using a colloid mill for $25 \mathrm{~min}$. The liquid impurities were filtered out with a 150-mesh sieve, and the solid parts were dried in an oven at $60^{\circ} \mathrm{C}$ for $24 \mathrm{~h}$ and then crushed. Ten times volume of distilled water was added and heated at $95^{\circ} \mathrm{C}$ for $30 \mathrm{~min}$. $1 \mathrm{M}$ hydrochloric acid was used to adjust pH to 5.6 , and $1.5 \%(\mathrm{w} / \mathrm{w})$ high-temperature resistant a-amylase was added. The reaction was stirred at $95^{\circ} \mathrm{C}$ for 30 min, and the complete reaction was detected with iodine solution. The temperature was lowered to $50^{\circ} \mathrm{C}$ and the $\mathrm{pH}$ was adjusted to 9.0 with $\mathrm{NaOH} .3 \%(\mathrm{w} / \mathrm{w})$ alkaline protease was added, and the reaction was stirred for $2 \mathrm{~h}$. The supernatant was discarded, filtered and rinsed through a 150-mesh sieve in clear water until the turbidity was reduced from the washed solution, and the remaining solid substances were dried in a $60^{\circ} \mathrm{C}$ oven for $24 \mathrm{~h}$. The wheat bran was obtained by drying and it was crushed by a micro grinder, screened with 100 mesh, dried in a constant temperature oven at $50^{\circ} \mathrm{C}$ overnight and then stored.

\section{Culture Medium}

PDA medium consisted of $200 \mathrm{~g} / \mathrm{L}$ potato, $20 \mathrm{~g} / \mathrm{L}$ glucose and $20 \mathrm{~g} / \mathrm{L}$ agar. The pH was neutral and it was sterilized at $1 \times 10^{5} \mathrm{~Pa}$ for $30 \mathrm{~min}$. Seed liquid medium consisted of $20 \mathrm{~g} / \mathrm{L}$ glucose, $2 \mathrm{~g} / \mathrm{L}$ yeast extract, $3 \mathrm{~g} / \mathrm{L} \mathrm{KH}_{2} \mathrm{PO}_{4}, 1.5 \mathrm{~g} / \mathrm{L} \mathrm{MgSO}{ }_{4} \cdot 7 \mathrm{H}_{2} \mathrm{O}$ and $0.5 \mathrm{~g} / \mathrm{L} \mathrm{VB}$. The pH was neutral and it was sterilized at

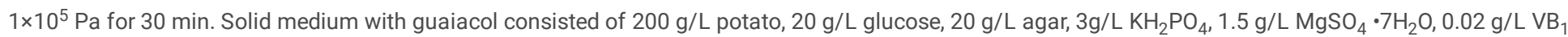
and $1 \mathrm{~g} / \mathrm{L}$ guaiacol. The $\mathrm{pH}$ was neutral and it was sterilized at $1 \times 10^{5} \mathrm{~Pa}$ for $30 \mathrm{~min}$. Basic medium for liquid fermentation consisted of $30 \mathrm{~g} / \mathrm{L}$ wheat bran, 3 $\mathrm{g} / \mathrm{L} \mathrm{KH}_{2} \mathrm{PO}_{4}, 1.5 \mathrm{~g} / \mathrm{L}, \mathrm{MgSO}_{4} \cdot 7 \mathrm{H}_{2} \mathrm{O}, 1.4 \mathrm{~g} / \mathrm{L}\left(\mathrm{NH}_{4}\right)_{2} \mathrm{SO}_{4}, 0.3 \mathrm{~g} / \mathrm{L} \mathrm{CaCl}, 5 \mathrm{mg} / \mathrm{L} \mathrm{FeSO}{ }_{4} \cdot 7 \mathrm{H}_{2} \mathrm{O}, 1.6 \mathrm{mg} / \mathrm{L}, \mathrm{MnSO}_{4} \cdot \mathrm{H}_{2} \mathrm{O}$ and $0.02 \mathrm{~g} / \mathrm{L}$ VB 1 . The pH was neutral and

it was divided into $250 \mathrm{~mL}$ triangular flasks, or $100 \mathrm{~mL}$ per bottle and sterilized at $1 \times 10^{5} \mathrm{~Pa}$ for 30 min. Cellulose solid medium was stained with Congo red, and the method used was as previously described by Kim et al., 2018). This medium consisted of $5 \mathrm{~g} / \mathrm{L}$ sodium carboxymethyl cellulose, $0.5 \mathrm{~g} / \mathrm{L}$ yeast extract, 0.5 $\mathrm{g} / \mathrm{L}$ peptone, $0.3 \mathrm{~g} / \mathrm{L}$, beef extract, $3 \mathrm{~g} / \mathrm{L}, \mathrm{KH}_{2} \mathrm{PO}_{4}, 5 \mathrm{~g} / \mathrm{L} \mathrm{K}{ }_{2} \mathrm{HPO}_{4}, 2 \mathrm{~g} / \mathrm{L},\left(\mathrm{NH}_{4}\right)_{2} \mathrm{SO}_{4}, 0.4 \mathrm{~g} / \mathrm{L} \mathrm{MgSO}, 0.1 \mathrm{~g} / \mathrm{L} \mathrm{CaCl}$, $1 \mathrm{~mL}$ of a trace element solution, $20 \mathrm{~g} / \mathrm{L}$ agar powder and $0.5 \mathrm{~g}$ Congo red powder dissolved in $50 \mathrm{~mL}$ sterile water.

\section{Isolation and Purification of Endophytic Fungi}

Healthy and disease-free haustorium of $T$. chinensis from different hosts were selected and the tissues were cut into $5 \mathrm{~cm}$ fragments. The surfaces were successively disinfected with $75 \%$ ethanol and $0.1 \% \mathrm{Hg}$ for $2.5 \mathrm{~min}$, and washed with sterile water three times ${ }^{38}$. Using sterile forceps and scalpels, they were cut into tissue blocks of about $5 \mathrm{~mm}$ in size, and then placed on PDA (medium containing streptomycin) plates with 5 blocks per plate and 3 plates per sample. The cultures were kept at $28^{\circ} \mathrm{C}$ until the mycelium grew from the edge of the tissue blocks, and then these were transferred to PDA plates for purification and preservation.

\section{Primary Screening of Ligno-cellulosic Degrading Enzyme Strains}

Preliminary screening of lignin degrading enzyme strains: $0.1 \%$ guaiacol were added into PDA medium in order to make the plates ${ }^{39}$. After purification, bacterial blocks with a diameter of $6 \mathrm{~mm}$ were selected and placed on the plates on a super-clean platform, with 3 parallel strains for each strain, and these were cultured at $28^{\circ} \mathrm{C}$ for 10 days. The diameters of colony and color circles within the plate were observed and statistically analyzed, as well as any changes in colony color.

Primary screening of cellulolytic enzyme strains was carried out by the following method. The tissue blocks ( 6 mm in diameter) of the purified strains were inoculated on the culture medium together with cellulose solid medium. For each group this was repeated 3 times and then incubated at $28{ }^{\circ} \mathrm{C}$ for 10 days. The cells were stained with $0.1 \%$ Congo red for $15 \mathrm{~min}$, and then decolorized with $1 \mathrm{M} \mathrm{NaCl}$ for $15 \mathrm{~min}$. Unit transparent circle diameter $=$ transparent circle diameter - colony diameter. It was deemed that the larger the diameter of the transparent circle, the higher the enzyme production activity 40 .

\section{Re-screening of Ligno-cellulosic Degrading Enzyme Strains}

The lignin cellulose-degrading enzyme strains with chromogenic and transparent rings were screened according to the above method.

\section{Liquid Enzyme Preparation}

The lignocellulose-degrading strains with chromogenic and transparent rings were selected for 5-7 d cultures, and these were quantitatively inoculated respectively. $10 \mathrm{~mL}$ of the shaken seed liquid was added into a $250 \mathrm{~mL}$ triangular flask containing $100 \mathrm{~mL}$ of liquid fermentation medium. Each strain was inoculated in 2 bottles, and in each bottle 5 strain blocks of $6 \mathrm{~mm}$ in diameter were added. These were incubated for 11 days in a constant temperature shaker at $26^{\circ} \mathrm{C}$ and $140 \mathrm{r} / \mathrm{min}$. Samples were taken from the fourth day of liquid culture, once daily. The fermentation liquid was filtered with four layers of gauze, and the filtrate was centrifuged at $3000 \mathrm{r} / \mathrm{min}$ for $15 \mathrm{~min}$. The supernatants were the crude enzyme liquid.

\section{Identification of Endophytic Fungi}

The colony morphology was recorded by referring to Fang Zhongda's method ${ }^{38}$, and this parameter was initially identified by referring to Wei Jingchao's method ${ }^{41}$ and the international classification website (http:// www.indexfungorum.org). Its rDNA (ITS1 5'-TCCGTAGGTGAACCTGCGG-3' and ITS4 5'TCCTCCGCTTATTGATATGC-3') and beta-tubulin (BT-2a) 5'-AACATGCGTGAGATTGTAAGT-3' and beta-tubulin (BT-2b) 5 '-ACCTCAGTGTAGTGACCTTGGC-3') were used for molecular biological identification ${ }^{42-43}$. Mightyamp DNA Polymerase Ver.3 (1.25U / 50 $\mu \mathrm{L}$ ) kit (Takara Bio Inc., Japan, Cat.No. R076A) was used to select endophyte colonies as templates for the PCR reaction. The target bands were detected by using the gel imaging method, and the PCR products of the 
target bands were sent to BGI (Guangzhou) Co. Ltd. for sequencing. The sequencing results were compared using BLAST with the sequences in the NCBI GenBank. The phylogenetic tree of ITS and tubulin gene was constructed using the Neighbor-Joining method with MEGA 7.0 software ${ }^{44}$.

\section{Determination of Enzyme Activity}

The enzyme activity of laccase was measured using ABTS as substrate ${ }^{45}$, which was defined as the amount of enzyme required for the catalytic oxidation of $1 \mu \mathrm{mol}$ of substrate ABTS at $30^{\circ} \mathrm{C}$ per minute as a unit of laccase activity. The oxidation of substrate ABTS was determined by measuring the light absorption value of the reaction solution at $420 \mathrm{~nm}$, and using a molar extinction coefficient of $36000 \mathrm{~L} \mathrm{~mol}^{-1} \mathrm{~cm}^{-1}$. Lignin peroxidase activity was measured by using veratrol as an oxidation substrate to produce veratrol at $30^{\circ} \mathrm{C}^{46}$. A unit of enzyme activity was defined as the change of absorbance value of 0.1 unit per $\mathrm{mL}$ of the reaction solution per minute. The activity of manganese peroxidase was measured by the phenol red method ${ }^{47}$. A unit of enzyme activity was defined as the increase of the light absorption value per $\mathrm{mL}$ of the reaction solution at $610 \mathrm{~nm}$ by 0.1 unit, expressed as $\mathrm{U} \cdot \mathrm{mL}^{-1}$.

Cellulase activity was determined by using a cellulase (CL) activity detection kit (Beijing Solaibuo Technology Co., Ltd.) and the 3.5-dinitrosalicylic acid (DNS) method. Under the action of cellulase, cellulose degrades to produce a reducing sugar, and the amount of reducing sugar was determined to determine enzyme activity. From the kit, $1 \mathrm{~mL}$ ultra-pure water was added to $10 \mathrm{mg}$ anhydrous glucose standard (dry weight loss $<0.2 \%$ ) to prepare a $10 \mathrm{mg} \mathrm{mL}^{-1}$ glucose solution, which was then diluted into $1.0,0.8,0.6,0.4,0.2,0.1$ and $0 \mathrm{mg} \mathrm{mL}^{-1}$ by gradient dilution. These were read at $540 \mathrm{~nm}$ to establish a standard curve. $1 \mathrm{~mL}$ of fermentation liquid was weighed and the bacteria were lysed in an ultrasonic ice bath. The supernatants were centrifuged at $4^{\circ} \mathrm{C}$ for 10 min at $8000 \mathrm{~g}$ and $2 \mathrm{~mL}$ of the crude enzyme liquid in centrifuge tubes were placed on ice to be measured. The reaction system was composed of $350 \mu \mathrm{L}$ of substrate and $50 \mu \mathrm{L}$ sample. After the reaction, the saccharification solution was obtained by boiling in order to terminate the reaction. $50 \mu \mathrm{L}$ of the saccharification solution was taken and $150 \mu \mathrm{L}$ DNS reagent was added and mixed. Then $1050 \mu \mathrm{L}$ of double distilled water was added to measure the absorbance at $540 \mathrm{~nm}$ under the UV spectrophotometer ${ }^{48-49}$.

\section{Statistical Analysis of Data}

Statistical results were expressed as $\mathrm{x} \pm \mathrm{s}$, with \pm being the mean value and $\mathrm{s}$ being the standard deviation. SPSS19.0 software was used to conduct univariate ANOVA analysis and the variance homogeneity test for data in each group. $\mathrm{P}<0.05$ was considered statistically significant.

\section{Results}

\section{Isolation of Endophytic Fungi}

A total of 147 strains were isolated from $T$. chinensis composed of seven host species. These were 32 strains of $M$. alba, 17 strains of $P$. salicina, 12 strains of $D$. kaki, 26 strains of $D$. longan, 10 strains of $P$. chinense, 27 strains of $D$. odorifera and 23 strains of $B$. purpurea. A total of 72 strains of strains with different morphological types were selected and the activities of lignin degrading enzyme and cellulase were assessed by using the plates.

\section{Determination of Lignin Degrading Enzyme Activity by Plate}

The microorganisms producing chromogenic circle on the selective medium with guaiacol as indicator had the ability to degrade lignin, and the hyphae of laccase producing strains growing on the medium produced an obvious reddish brown coloration. 72 strains were cultured on guaiacol selective medium plates for 11 days, and the discoloration of each plate was observed and recorded on days $3,5,7,9$ and 11 . The results showed that 11 strains had neither colony circle nor chromogenic circles. 17 strains had the ratio of colony circle diameter to chromogenic circle diameter of less than 1 . There were 26 strains with the ratio of colony diameter to chromograph diameter greater than 1 . There were 7 strains with chromogenic circles but without colony circles. There were 11 strains with colonies but without chromogenic circles. According to Eriksson et al., 2012, the ratio of the diameter of colony circle to chromophore can be used to judge whether the bacteria can selectively degrade lignin. If the ratio is less than 1 , the bacteria can selectively degrade lignin. In summary, after qualitative preliminary screening and re-screening by the guaiacol method, a total of 5 strains with large and obvious chromogenic circles were screened out from 24 strains (strains with a ratio of colony circle diameter to chromogenic circle diameter of less than 1 and strains with chromogenic circles but without colonies) for subsequent enzyme activity tests (Table 1). It can be seen from Table 1 that the colonies and chromogenic circles of these 5 plants also increased with the growth time period, and neither of them increased until day 11. Figure 1 shows the growth of the five strains on the PDA color plate after day 7.

TABLE 1 Diameter changes of colony and chromogenic circles of different strains on selective media indicating lignin degradation ability over time (cm).

\begin{tabular}{|c|c|c|c|c|c|c|c|c|c|}
\hline \multirow[t]{2}{*}{ Strains } & \multicolumn{2}{|l|}{$3 d$} & \multicolumn{2}{|l|}{$5 d$} & \multicolumn{2}{|l|}{$7 d$} & \multicolumn{2}{|l|}{$9 d$} & \multirow{2}{*}{$\begin{array}{l}11 d \\
C\end{array}$} \\
\hline & $\mathrm{C}$ & $\mathrm{CR}$ & C & $\mathrm{CR}$ & $\mathrm{C}$ & $\mathrm{CR}$ & $\mathrm{C}$ & $\mathrm{CR}$ & \\
\hline 4 & $0.00 \pm 0.00 \mathrm{a}$ & $1.30 \pm 0.17 a$ & $0.00 \pm 0.00 a$ & $1.50 \pm 0.06 a$ & $0.00 \pm 0.00 a$ & $1.70 \pm 0.06 a$ & $1.70 \pm 0.06 a$ & $2.90 \pm 0.11 a$ & 1.70: \\
\hline 15 & $0.00 \pm 0.00 a$ & $1.30 \pm 0.06 a$ & $0.00 \pm 0.00 a$ & $1.70 \pm 0.12 \mathrm{ab}$ & $0.00 \pm 0.00 a$ & $2.20 \pm 0.05 b$ & $2.20 \pm 0.10 \mathrm{~b}$ & $2.80 \pm 0.11 \mathrm{ab}$ & 2.20: \\
\hline 31 & $1.30 \pm 0.14 b$ & $2.10 \pm 0.12 b$ & $1.50 \pm 0.06 b$ & $2.80 \pm 0.23 c$ & $1.70 \pm 0.12 b$ & $3.00 \pm 0.06 c$ & $2.60 \pm 0.12 c$ & $3.10 \pm 0.06 \mathrm{ac}$ & 2.60: \\
\hline N6 & $1.00 \pm 0.05 c$ & $0.00 \pm 0.00 c$ & $1.50 \pm 0.17 b$ & $2.10 \pm 0.12 \mathrm{bd}$ & $2.30 \pm 0.06 c$ & $3.50 \pm 0.05 d$ & $3.10 \pm 0.12 d$ & $4.50 \pm 0.17 d$ & 3.10: \\
\hline P6 & $0.00 \pm 0.00 a$ & $1.80 \pm 0.12 b d$ & $0.00 \pm 0.00 a$ & $2.20 \pm 0.23 \mathrm{be}$ & $0.00 \pm 0.00 a$ & $3.00 \pm 0.12 \mathrm{ce}$ & $1.50 \pm 0.17 \mathrm{ae}$ & $3.40 \pm 0.12 \mathrm{ce}$ & 1.50: \\
\hline
\end{tabular}

Note: $\mathrm{C}$ is for Circle of the colony; $\mathrm{CR}$ is for Color ring. Mean values are marked with different lower case letters are significantly different $(\mathrm{P}<0.05)$ 
With respect to the cellulose solid medium plate culture from 72 strains at day 11 , inspection of the plates on days $3,5,7,9$ and 11 , showed 14 strains had no transparent colony circles. The ratio of colony diameter to transparent circle diameter was less than 1 in 58 strains. The other strains had the ratio of colony free diameter to transparent diameter of greater than 1. Similarly, strains with the same lignin degrading enzyme were selected from strains with the ratio of colony circle diameter to transparent circle diameter less than 1 for subsequent enzyme activity test (Table 2). As can be seen from Table 2, these 5 strains gradually grew larger with time, and remained unchanged until 9 days while maintaining the original value range. Figure 2 shows the chromogenic growth of these five strains on cellulose solid medium at day 7.

TABLE 2 Diameter changes of colony and transparent circles of different strains on selective media indicating cellulose degradation ability over time (cm).

\begin{tabular}{|c|c|c|c|c|c|c|c|c|}
\hline \multirow[t]{2}{*}{ Strains } & \multicolumn{2}{|l|}{$3 d$} & \multicolumn{2}{|l|}{$5 d$} & \multicolumn{2}{|l|}{$7 d$} & \multicolumn{2}{|l|}{$9 d$} \\
\hline & $\mathrm{C}$ & $\mathrm{T}$ & $\mathrm{C}$ & $\mathrm{T}$ & $\mathrm{C}$ & $\mathrm{T}$ & C & $\mathrm{T}$ \\
\hline 4 & $4.50 \pm 0.06 a$ & $5.00 \pm 0.06 a$ & $5.00 \pm 0.06 a$ & $5.00 \pm 0.06 a$ & $5.20 \pm 0.17 a$ & $5.20 \pm 0.17 a$ & $5.20 \pm 0.17 a$ & $5.20 \pm 0.17 a$ \\
\hline 15 & $3.90 \pm 0.05 b$ & $4.60 \pm 0.06 b$ & $3.90 \pm 0.23 b$ & $4.60 \pm 0.06 b$ & $4.20 \pm 0.17 b$ & $4.60 \pm 0.06 b$ & $4.20 \pm 0.17 b$ & $4.60 \pm 0.06 b$ \\
\hline 31 & $4.60 \pm 0.06 \mathrm{ac}$ & $5.70 \pm 0.23 c$ & $5.70 \pm 0.17 c$ & $5.70 \pm 0.23 c$ & $5.80 \pm 0.29 c$ & $6.00 \pm 0.06 c$ & $5.80 \pm 0.29 c$ & $6.00 \pm 0.06 c$ \\
\hline N6 & $3.70 \pm 0.05 b d$ & $3.90 \pm 0.06 d$ & $3.90 \pm 0.06 \mathrm{bd}$ & $4.20 \pm 0.06 d$ & $3.90 \pm 0.18 b d$ & $4.20 \pm 0.17 d$ & $3.90 \pm 0.18 b d$ & $4.20 \pm 0.17 d$ \\
\hline P6 & $4.40 \pm 0.12 \mathrm{ae}$ & $4.60 \pm 0.12 \mathrm{be}$ & $4.60 \pm 0.12 \mathrm{ae}$ & $4.80 \pm 0.12 \mathrm{ab}$ & $4.60 \pm 0.00 \mathrm{be}$ & $4.80 \pm 0.12 \mathrm{be}$ & $4.60 \pm 0.00 \mathrm{be}$ & $4.80 \pm 0.12 \mathrm{be}$ \\
\hline
\end{tabular}

Note: $\mathrm{C}$ is for Circle of the colony; $\mathrm{T}$ is for transparent circle. Mean values are marked with different lower case letters are significantly different $(\mathrm{P}<0.05)$

\section{Identification of Strains}

A phylogenetic tree was constructed by combining ITS rDNA sequences and beta-tubulin sequences, and the results (Figure 3) showed that stains 4, 15, 31, N6 and P6 were correlated with Colletotrichum acutatum (CBS MH860607), Nigrospora sphaerica (CBS MH854878), Exserohilum rostratum (MH865917), Diaporthe phaseolorum (CBS KC343174\ KC343175 KC343176), and Pestalotiopsis arceuthobii (CBS MH858656). These species in the same branch and the similarity is $99 \%-100 \%$. Therefore, these five strains were identified as C. acutatum, N. sphaerica, E. rostratum, D. phaseolorum and P. arceuthobii, respectively. Sequences of these five strains were submitted to the GenBank database and the accession numbers obtained (ITS and beta-tubulin) are MZ2823601/MZ964759, MZ2823600/ MZ934421, MZ2823597/ MZ934418, MZ2823599/ MZ934420 and MZ2823598/ MZ934419, respectively.

\section{Activity Analysis of Lignin Degradation Enzyme System}

\section{Determination of Laccase Activity}

As can be seen from Figure 4-A, the peak time of laccase production of these five strains was on day 7, and this began to decline from day 9 . The laccase production capacity of the 5 strains was significant $(\mathrm{P}<0.05)$. Among them, $P$. arceuthobii had the strongest laccase production capacity $(117.66 \mathrm{U} / \mathrm{mL})$, followed by $D$. phaseolorum, $N$. sphaerica and $E$. rostratum $(51.82,32.11$ and $21.85 \mathrm{U} / \mathrm{mL}$, respectively), and $C$. acutatum had the weakest laccase production activity $(9.76 \mathrm{U} / \mathrm{mL})$. The order of enzyme activities of the five strains was $P$. arceuthobii $D$. phaseolorum $\llbracket$. sphaerica!E. rostratum $C$. acutatum.

\section{Determination of Manganese Peroxidase Activity}

As shown in Figure 4-B, the highest value of manganese peroxidase production by $C$. acutatum was 7 days, with the enzyme activity of $11.61 \mathrm{U} / \mathrm{mL}$, followed by $D$. phaseolorum and E. rostratum, with the highest enzyme activities of 8.47 and $5.58 \mathrm{U} / \mathrm{mL}$, respectively. On the other hand, $N$. sphaerica and P. arceuthobii had the highest enzyme production capacity at day 11 , and the enzyme activities were 8.59 and $6.79 \mathrm{U} / \mathrm{mL}$, respectively. The maximum activity size of manganese peroxidase of the five strains was $C$. acutatum $>N$. sphaerica $>D$. phaseolorum $>P$. arceuthobii $>$ E. rostratum, and the difference was significant $(P<0.05)$.

\section{Determination of Lignin Oxidase Activity}

As shown in Figure 4-C, the lignin peroxidase activity curves of $D$. phaseolorum, $C$. acutatum, E. rostratum all increased first with the change of time, reached the peak of enzyme activity and then began to decline. The highest lignin peroxidase production capacity of these three strains was at 7 days, and the enzyme activities were $6.64,3.0$ and $2.9 \mathrm{U} / \mathrm{mL}$, respectively. The lignin peroxidase activities of $P$. arceuthobii and $N$. sphaerica increased at first, then decreased and then began to increase again on day 11 , with the highest enzyme activities of 4.21 and $3.4 \mathrm{U} / \mathrm{mL}$, respectively. The order of lignin peroxidase activity of the five strains was $D$. phaseolorum $\square$. arceuthobi $\square$. sphaerica $C$. acutatum $E$. rostratum, and the values of the enzyme activities at the lowest and the highest values of the five strains were significantly different $(P<0.05)$.

\section{Activity Analysis of Cellulolytic Enzymes}

From Figure 4-D, it can be seen that the cellulose enzyme activities of the four strains, P. arceuthobii, D. phaseolorum, E. rostratum and C. acutatum first rise until a peak is reached at day 5 , and then decline. However, for $N$. sphaerica a sudden drop is seen at day 5 and then a rise at day 7 followed by a decrease. In all the five strains, cellulase production at day 7 was at its highest. The cellulase activites were $1.66,1.61,0.67,0.61$ and $0.59 \mathrm{U} / \mathrm{mL}$ at day 7 in $P$. arceuthobii, D. phaseolorum, E. rostratum, C. acutatum and N. sphaerica, respectively. 


\section{Discussion}

In this study, wheat bran was selected as the substrate of lignin fiber biomass for fermentation, and the activities of laccase, manganese peroxidase, lignin peroxidase and cellulase were determined at different times. It was found that the maximum activity time of the five strains producing laccase and cellulase was 7 days, and the highest activities of laccase and cellulase were found in strain P6, which were 117.66 and $1.66 \mathrm{U} / \mathrm{mL}$, respectively. P. arceuthobii was identified by their morphological and molecular biology characteristics. It has been reported that Pestalotiopsis sp. fungus can produce relatively high laccase and cellulose activities, and can effectively degradation forest litter ${ }^{25}$. Moreover, it was found that the color of fermentation broth extracts of $P$. arceuthobii was significantly lighter than those of the other four strains. This is because laccase can be used with the decolorization and degradation of fuel and can potentially be used against global warming strategies ${ }^{26-27}$. P. arceuthobii produced the highest laccase activity of $117.66 \mathrm{U} / \mathrm{mL}$, which was a relatively high value when compared to the unpurified crude enzyme activities reported at present, and its production did not depend on the addition of some inducible factors such as soil temperature $80^{\circ} \mathrm{C}$, ferulic acid, $\mathrm{Cu}^{2+}$ or dimethylaniline. Moreover, it was reported by Cao et al. ${ }^{28}$ that the enzyme activity of laccase with the addition of a soil temperature of $80{ }^{\circ} \mathrm{C}$ and a $\mathrm{Cu}^{2+}$ inducer was indeed much higher within a week of growth. However, except for the white rot fungus, Ganoderma applanatum, the average value of laccase activity of other two white rot fungi (Trametes hirsuta and Fomes fomentarius) did not reach their peak values. These results indicate that $P$. arceuthobii is a relatively effective laccase producing strain.

The peak activities of manganese and lignin peroxidases of the $D$. phaseolorum, $C$. acutatum, $N$. sphaerica and E. rostratum also appeared on day 7 , but the second peak of manganese peroxidase activities of strain $N$. sphaerica and $P$. arceuthobii on day 11 were 8.59 and $6.79 \mathrm{U} / \mathrm{mL}$, respectively. The enzyme activities of lignin peroxidase were 3.4 and $4.21 \mathrm{U} / \mathrm{mL}$, respectively, which were consistent with the reports regarding lignase and cellulase of some white rot fungi ${ }^{29-31}$. The second peak may be due to the release of the corresponding intracellular enzymes that were originally bound to the cell membranes due to autolysis of the hyphae ${ }^{25}$. The four strains of $\mathrm{N} 6,4,15$ and 31 were identified by their morphological and molecular biology characteristics as $D$. phaseolorum, C. acutatum, N. sphaerica, E. rostratum, respectively. This is the first report of four fungi which produce lignocellulose-degrading enzymes using wheat gluten fibrous biomass as a substrate. Some previous studies have also investigated the activities of laccase, lignin peroxidase, manganese peroxidase and cellulase produced by fungi of six less common fungi (Alternaria sp., Penicillium sp., Cephalosporium sp., Tricherderma sp., Pestalotiopsis sp. and Aspergillus fumigates) during the degradation of Masson pine leaf $l i t t e r^{25}$.

The degradation of lignin and cellulose is not dependent on a single enzyme, but the result of the interactions of several enzymes. Lignin degradation enzymes mainly consist of three enzymes: lignin peroxidase, manganese peroxidase and laccase ${ }^{32}$. Moreover, the size of the color circle is necessarily related to the level of laccase activity, but there is not a positive linear correlation between these two parameters ${ }^{33}$. Cellulose-degrading enzymes mainly consist of an endoglucanase, an exoglucanase and $\beta$-glucosidase, and the synergistic action of these three enzymes is required for the complete hydrolysis of cellulose into monosaccharides ${ }^{34-36}$.

\section{Declarations}

\section{Ackowledgements}

This work was supported by the National Natural Science Foundation of China (Nos. 81703649, 81860672, 81960695 and 82173933 ) and the Guangxi Natural Science Foundation of China (Nos. 2016GXNSFDA380012, 2017GXNSFDA198026, 2018GXNSFAA281089 and 2021 GXNSFBA075037), Guangxi Botanical Garden of Medicinal Plants Research and Innovation Team Building Project (No. GYCH2019008) and the Scientific Research Funding Project of Guangxi Botanical Garden of Medicinal Plants (No. GYJ202012). The authors are also grateful to Dr. Dev Sooranna of Imperial College London for English language editing of the final manuscript.

\section{Author Contributions}

Reviewed and finalized manuscript, SG Wei and JE Fu, completed the writing of the article, LS Song and L.M Pan, integrating and analysis of the data in the Tables and made Figures: N Jiang and overseeing the completed manuscript: L Y Wan.

\section{Additional Information}

Competing interests: The authors declare no competing interests.

Publisher's note: Springer Nature remains neutral with regard to jurisdictional claims in published maps and institutional affiliations.

\section{References}

1. China Pharmacopoeia Committee. Chinese pharmacopoeia, the first part 312 (China Medicine Science and Technology Press, Beijing, 2020).

2. Pritchard, H. W. Water potential and embryonic axis viability in recalcitrant seeds of quercus rubra.Annals of Bot. 67,43-49(1991)

3. Li, Y. H., Lu, D., Zhao, M. H. \& Zhu, K. X. Research on the developments and applications for medicinal plants of loranthaceae in Guangxi.Guangxi Medical Journal28,1695-1698(2006)

4. Nagar, R., Singh, M. \& Sanwal, G. G. Cell-wall degrading enzymes in Cuscuta reflexa and its hosts. J. Exp. Bot, 35, 1104-1112 (1984).

5. Ranjan, A. et al. De novo assembly and characterization of the transcriptome of the parasitic weed dodder identifies genes associated with plant parasitism. Plant Physiol, 166, 1186-1199 (2014). 
6. Johnsen, H. R. et al. Cell wall composition profiling of parasitic giant dodder (Cuscuta reflexa) and its hosts: a priori differences and induced changes. New Phytol, 207, 805-16 (2015).

7. Olsen, S. et al. Getting ready for host invasion: elevated expression and action of xyloglucan endotransglucosylases/hydrolases in developing haustoria of the holoparasitic angiosperm Cuscuta. J. Exp. Bot, 67, 695-708 (2016).

8. LeBlanc, M., Kim, G., Patel, B., Stromberg, V. \& Westwood, J. Quantification of tomato and Arabidopsis mobile RNA s trafficking into the parasitic plant Cuscuta pentagona. New Phytol, 200, 1225-1233 (2013).

9. Haupt, S., Oparka, K. J., Sauer, N. \& Neumann, S. Macromolecular trafficking between Nicotiana tabacum and the holoparasite Cuscuta reflexa. J. Exp. Bot, 52, 173-177 (2001).

10. Neumann, V. B., Weber, H. C. \& Sallé, G. Interface between haustoria of parasitic members of the Scrophulariaceae and their hosts: A histochemical and immunocytochemical approach. Protoplasma, 207, 84-97 (1999).

11. Naseer, S. et al. Casparian strip diffusion barrier in Arabidopsis is made of a lignin polymer without suberin. P. Natl. Acad. Sci. Usa, 109, 10101-10106 (2012).

12. Pérez-de-Luque, A.. Haustorium invasion into host tissues. In Parasitic Orobanchaceae, D.M. Joel, J. Gressel, and L.J. Musselman, eds. (Berlin,Heidelberg:SpringerBerlin Heidelberg) 75-86(2013)

13. Ben-Hod, G., Losner, D., Joel, D. M. \& Mayer, A. M. Pectin methylesterase in calli and germinating seeds of Orobanche aegyptiaca., 32, 1399-1402 (1993).

14. Losner-Goshen, D., Portnoy, V. H., Mayer, A. M. \& Joel, D. M. Pectolytic activity by the haustorium of the parasitic plant Orobanche L. (Orobanchaceae) in host roots. Ann. Bot, 81, 319-326 (1998).

15. Olsen, S. \& Krause, K. Activity of xyloglucan endotransglucosylases/hydrolases suggests a role during host invasion by the parasitic plant Cuscuta reflexa. Plose One, 12, e0176754 (2017).

16. Martinez, D. et al. Genome sequence of the lignocelluloses degrading fungus Phanerochaete chrysosporium strain RP78. Nature Biotechnolgy, 22, 695700 (2004).

17. Martinez, D. et al. Genome, transcriptome, and secretome analysis of wood decay fungus Postia placenta supports unique mechanisms of lignocelluloses conversion. PNAS, 106, 1954-1959 (2009).

18. Fernandez-Fueyo, E. et al. Comparative genomics of Ceriporiopsis subvermispora and Phanerochaete chrysosporium provide insight into selective ligninolysis. PNAS, 109, 5458-5463 (2012).

19. Xu, C. F. et al. Microbial degradation of lignocellulose. Chin J Biotech, 35, 2081-2091 (2019).

20. Hakala, T. K. et al. Manganese peroxidases, laccases and oxalic acid from the selective white-rot fungus Physisporinus rivulosus grown on spruce wood chips. Enzyme and Microbial Technology, 36, 461-468 (2005).

21. Kirk, T. K. \& Jeffries, T. W. Roles for microbial enzymes in pulp and paper processing. Enzymes for pulp and paper processingpp 2-14(ACS, Washington, 1996).

22. Ander, P. \& Eriksson, K. E. Selective degradation of wood components by white-rot fungi. Physiol. Plantarum, 41, 239-248 (1977).

23. Xiong, Y. Screening and identification of Lignocellulose degrading bacteria and degradation products research.Shanxi (Shanxi Agricultural University, 2019).

24. Xu, A. M., Li, L. \& Ma, S. Screening of lignin degrading enzyme high-producing strain from white rot fungi. Journal of Henan University of Technology (Natural Science Edition), 41, 78-82, 89((2020).

25. Hao, J. J. et al. Decomposition of pinus massoniana needle driven by deuteromycetes-dynamics of lignocellulolytic enzymes. Scientia silvae sinicae42,69-75

26. Thurston, F. C. The structure and function of fungal laccase., 140, 19-26 (1994).

27. Wong, Y. \& Yu, J. Laccase catalysed decolorization of synthetic dyes. Water Res, 33, 3512-3520 (1999).

28. Cao, Y. J., Ma, H. F., Cui, B. K., Si, J. \& Dai, Y. C. Lignocellulolytic enzyme activities of three white rot fungi under different solid-state fermentation media. Mycosystema, 40, 1-17 (2021).

29. Ruttimann, C., Schwember, E., Salas, L. \& Cullen, D. Ligninolytic enzymes of white rot basidiomycete Phlebisbrevispora and Cereporiopsis subvermispora. Biotechnol. Appl. Biochem, 16, 64-76 (1992).

30. Raghukumar, C., D'Souza, T. M., Thorn, R. G. \& Reddy, C. A. Lignin modifying enzymes of Flavodon flavus, a basidiomycete isolated from costal marine environment. Appl. Environ. Microbiol, 65, 2103-2111 (1999).

31. Arora, D. S. \& Gill, P. K. Laccase production by some white-rot fungi under different nutritional conditions. Bioresour Technol, 73, 283-285 (2000).

32. Chi, Y. J. \& Yi, H. W. Lignin degradation mechanisms of ligninolytic enzyme system, manganese peroxidase, laccase and lignin peroxidase, produced by wood white rot fungi. Mycosystema, 26, 153-160 (2007).

33. Du, H. P., Song, R. Q. \& Wang, Y. Q. Comparative sudy on the Ignocellulolytic ezymes poduced by fungi. Forestry science \& technology, 31, 20-24 (2006).

34. Wilson, D. B. Cellulases and biofuels. Curr. Opin. Biotech, 20, 295-299 (2009).

35. Linton, S. M. Review: the structure and function of cellulase (endo- $\beta-1,4-g l u c a n a s e)$ and hemicellulase( $\beta$-1,3-glucanase and endo- $\beta$-1,4-mannase) enzymes in invertebrates that consume materials ranging from microbes, algae to leaf litter. Comp. Biochem. Phys. B, 240, 110354 (2020).

36. Siqueira, J. G. W., Rodrigues, C., Vandenberghe, L. P. D. S., Woiciechowski, A. L. \& Soccol, C. R. Current advances in on-site cellulase production and application on lignocellulosic biomass conversion to biofuels: a review. Biomass Bioenerg, 132, 105419 (2020).

37. Tao, Y. Y. Study on the modification and application of wheat bran dietary fibre (Jiangnan University, Wuxi, 2008).

Page 7/10 
38. Fang, Z. D. Research methods on plant diseases (China Agriculture Press, Beijing, 1998).

39. Sun, H. H. Study on potential ability of several edible fungi biodegradation of lignocelluloses of straw (Nanjing Agricultural University, Nanjing, 2012).

40. Kim, E. S. et al. Aerobic and anaerobic cellulose utilization by Paenibacillus sp. CAA11 and enhancement of its cellulolytic ability by expressing a heterologous endoglucanase. J. Biotechnol, 268, 21-27 (2018).

41. Wei, J. C. Fungal identification manual (Shanghai Scientific and Technical Publishers, Shanghai, 1979).

42. White, T. J., Bruns, T., Lee, S. \& Taylor, J.. Amplification and direct sequencing of fungal ribosomal RNA genes for phylogenetics. In: Innis MA, Gelfand DH,

Sninsky JJ, WhiteTJ (eds) PCR protocols, a guide to methods and applications.Academic Press, San Diego,pp315-322(1990)

43. Weir, B. S. \& Johnston, P. R. Damm, U. The Colletotrichum gloeosporioides species complex. Stud Mycol, 73, 115-180 (2012).

44. Kumar, S., Stecher, G. \& Tamura, K. MEGA7:Molecular Evolutionary Genetics Analysis version 7.0 for bigger datasets. Mol. Biol. and Evol, 33, 1870-1874 (2016).

45. Buswell, J. A., Cai, Y. J. \& Chang, S. T. Effect of nutrient nitrogen and manganese on manganese peroxidase and laccase production by Lentinula edodes. FEMS Microbiol Lett, 128, 81-88 (1995).

46. Tien, M. \& Kirk, T. K. Lignin peroxidase of Phanerochaete chrysosporium. Methods Enzymol, 161, 238-249 (1988).

47. Orth, A. B. \& Tien, M. Ubiquity of lignin degrading peroxidases among various wood degrading fungi. Appl. Environ. Microbiol, 59, 4017-4023 (1993).

48. Xie, C. X., Sun, J. Z. \& Li, C. L. Zhu D.C. Exploring the lignin degradation by bacteria. Microbiology China, 42, 1122-1132 (2015).

49. Ke, L. X., Wang, M. Y. \& WuQ.An exploratory study on elevation of the lignin degradation enzyme activity of Pleurotus ostreatus in submerged cultivation and its decolorization rate to direct sky blue 5B. Acta Scientiae Circumstantiae 35, 1449-1456 (2015)

\section{Figures}
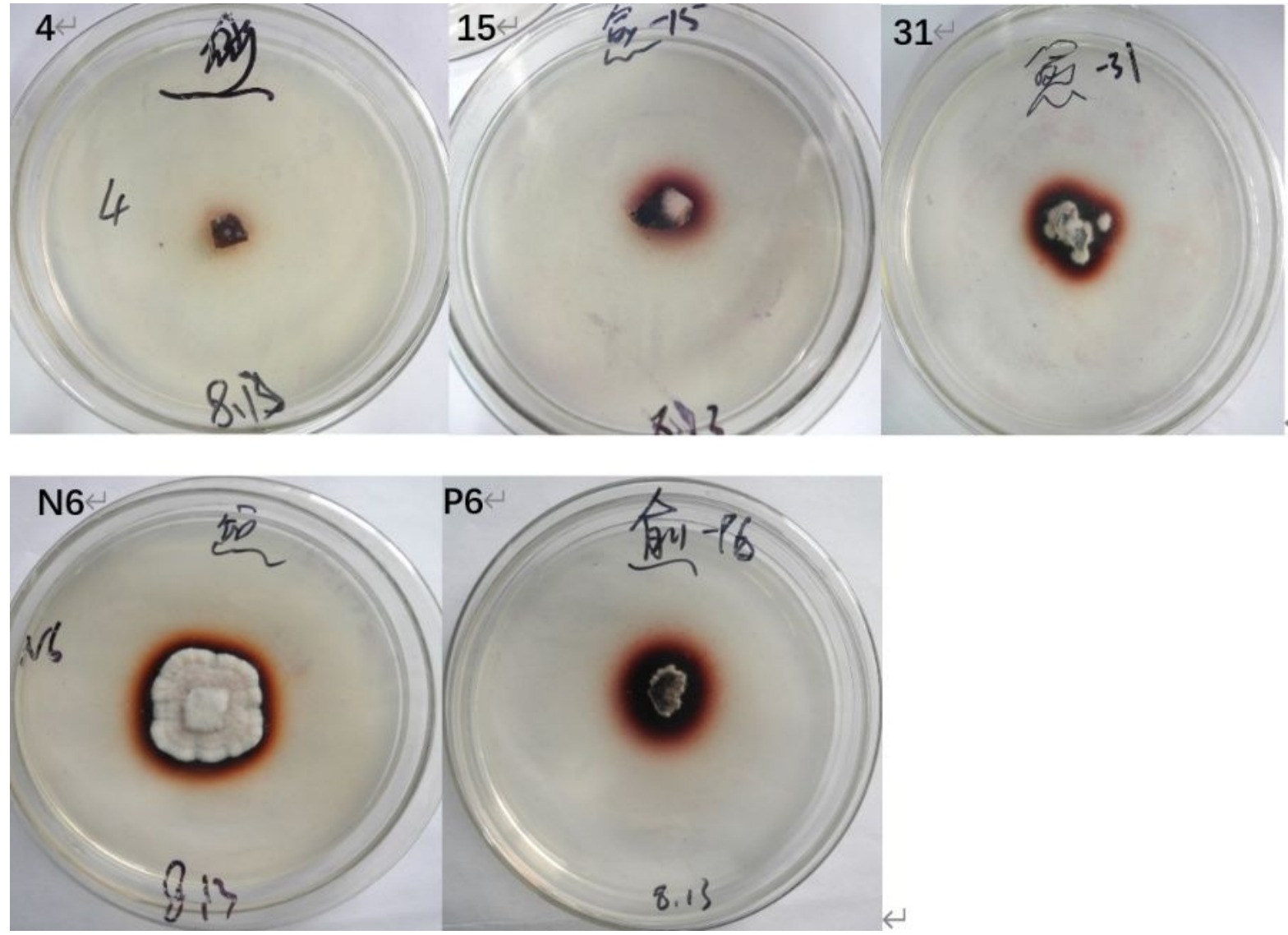

Figure 1

Growth diagrams of different strains on the PDA color plate on the 7th day. Note: 4 represents Colletotrichum acutatum; 15 represents Nigrospora sphaerica; 31 represents Exserohilum rostratum; N6 represents Diaporthe phaseolorum; P6 represents Pestalotiopsis arceuthobii. 

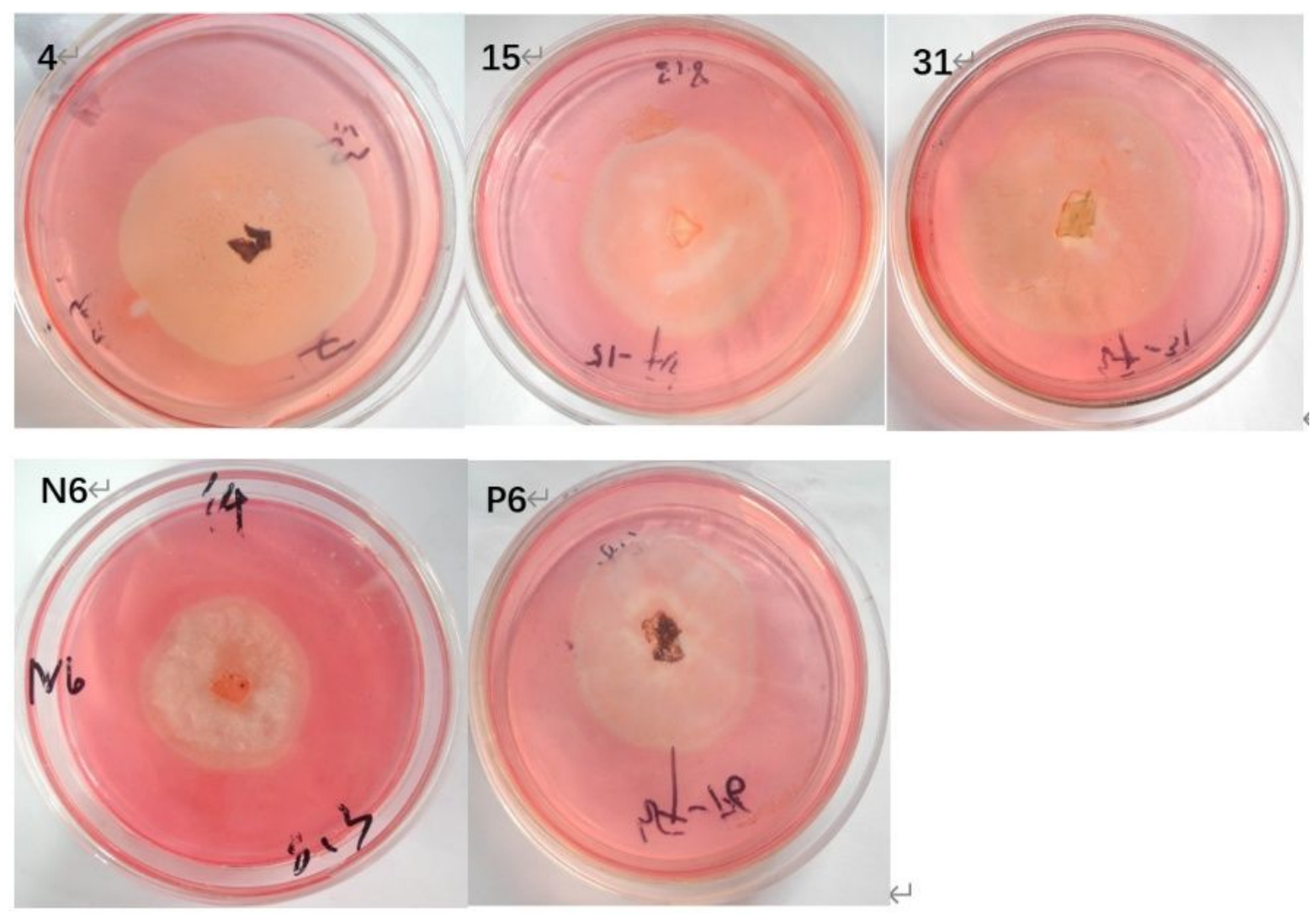

\section{Figure 2}

Growth diagrams of different strains on the Congo red agar plates on the day 7. Note: 4, 15, 31, N6 and P6 represent Colletotrichum acutatum, Nigrospora sphaerica, Exserohilum rostratum, Diaporthe phaseolorum, and Pestalotiopsis arceuthobii, respectively.

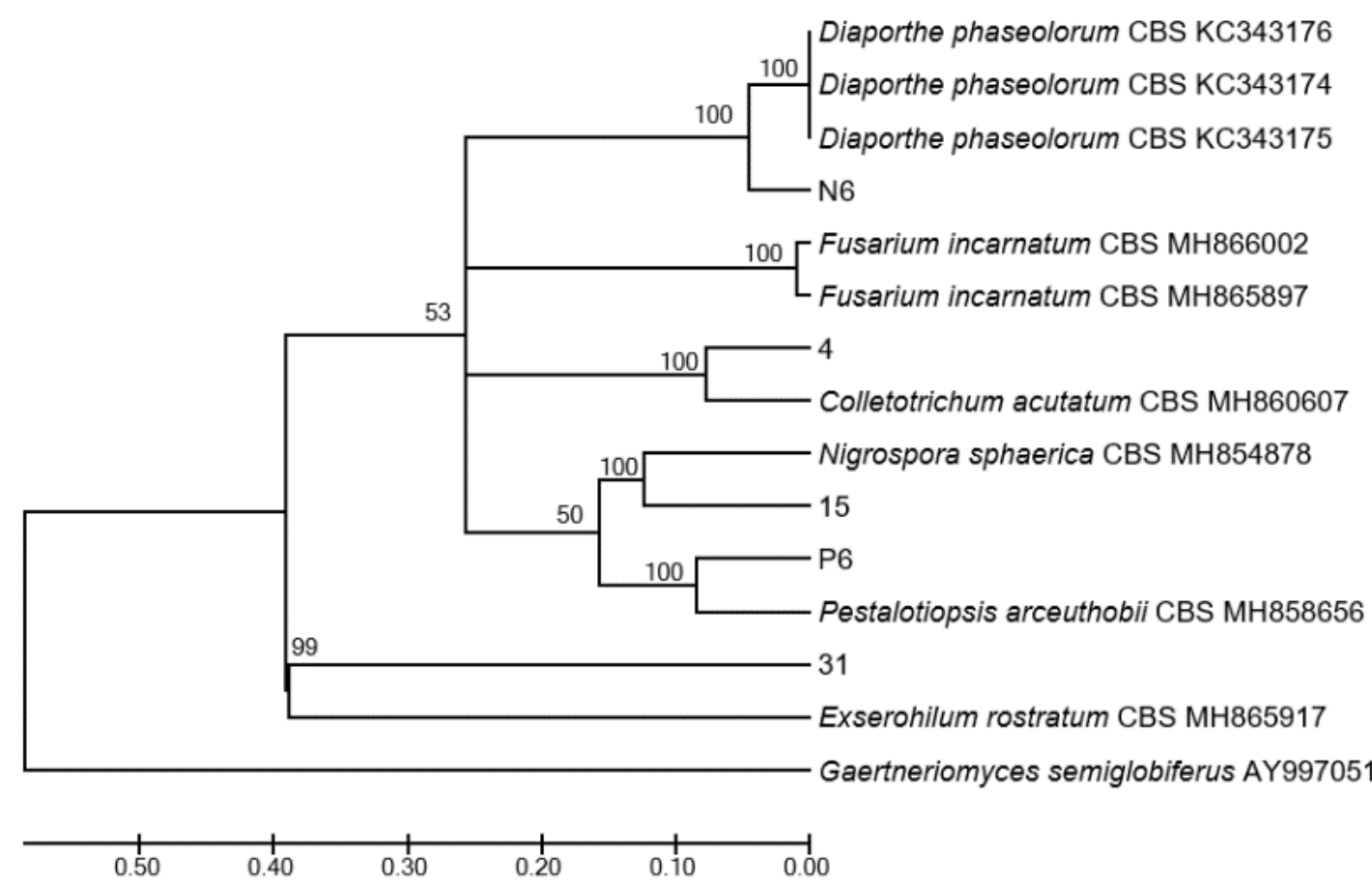

Figure 3

Phylogenetic tree constructed based on ITS rDNA and beta-tubulin sequences. 

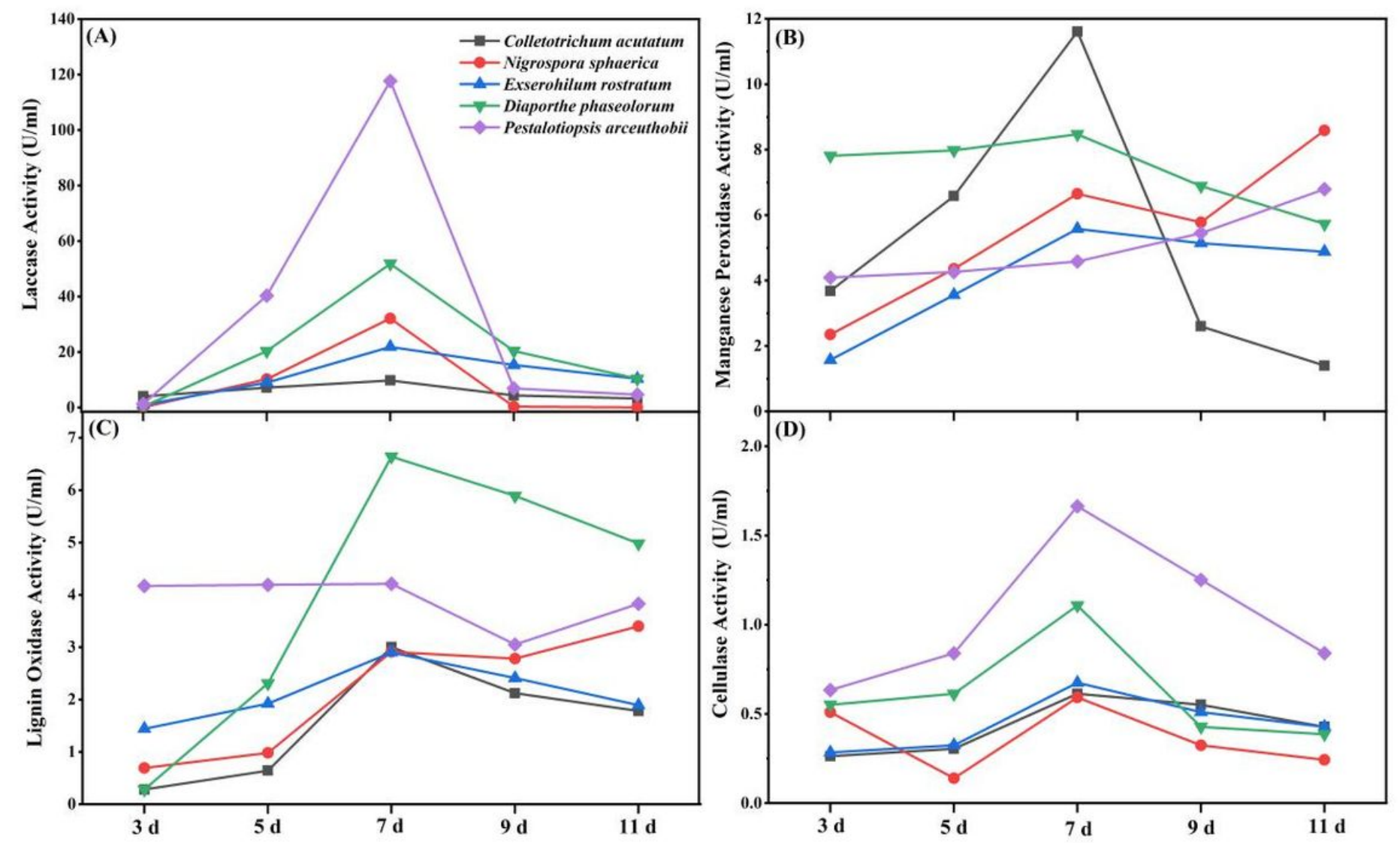

Figure 4

Variations of relevant enzyme activities produced by different endophytic fungi over time during lignin and cellulose degradation: (A) Laccase Activity; (B) Manganese Peroxidase Activity; (C) Lignin Oxidase Activity; (D) Cellulase Activity 